\title{
Carnaval de São Vicente: um produto turístico entre o cultural e o económico ${ }^{1}$
}

\author{
Carmo Daun e Lorena* \\ CRIA - Centro em Rede de Investigação em Antropologia (Portugal)
}

\begin{abstract}
Resumo: A ilha de São Vicente elegeu o carnaval como um dos seus atrativos turísticos principais e tudo tem feito para o fomentar. Este artigo pretende explorar as facetas cultural e económica do carnaval de São Vicente e analisar estes dois aspetos distintos, mas interligados, dando conta da evolução da promoção turística do carnaval através das disputas e investimentos simbólicos e financeiros que esta festa tem suscitado. A reflexão e o material que aqui apresento derivam de pesquisa etnográfica e arquivística e procuram caracterizar o processo de instituição do carnaval enquanto produto turístico emblemático da ilha. Sugiro que o potencial turístico da festa carnavalesca tem sido equacionado ao longo do tempo precisamente na confluência e intersecção das retóricas culturalista e economicista associadas ao carnaval, revelando-o assim como recurso simultaneamente económico e cultural, tal como é entendido pelos atores locais.
\end{abstract}

Palavras-chave: Cabo Verde; Carnaval; Turismo; Tradição; Cultura.

\section{São Vicente Carnival: a touristic product between the cultural and the economic}

Abstract: The island of São Vicente has chosen carnival as one of its main tourist attractions and has been doing everything to promote it. This article pretends to explore the cultural and economic dimensions of São Vicente carnival, and to analyze these two different but interconnected features, by accounting for the evolution of the touristic promotion of carnival through the disputes and symbolic and financial investments that this festivity has generated. The reflection and the data I present here derive from ethnographic and archival research and seek to characterize the institutionalization process of the carnival as an emblematic touristic product of the island. I suggest that the touristic potential of the carnival feast has been thought over time precisely in the confluence and intersection of the culturalist and economistic discourses associated to carnival, thus revealing it simultaneously both as an economic and cultural resource, as it is understood by local actors.

Keywords: Cape Verde; Carnival; Tourism; Tradition; Culture.

\section{Introdução}

Após um período de descaso, o turismo conta hoje, no campo das ciências sociais, com um importante e já consolidado historial de investigação, cujos diversos enfoques e abordagens demonstram bem a riqueza deste objeto de estudo. Não me ocuparei aqui dessa vasta literatura académica e está também fora dos meus propósitos examinar a que tem sido produzida para o caso cabo-verdiano. Cumpre dizer, aliás, que, ao contrário do que seria de presumir, Cabo Verde não tem recebido muita atenção das ciências sociais e humanas no que às suas dinâmicas turísticas diz respeito. ${ }^{2}$ Algo que surpreende, desde logo, pela centralidade que o turismo assume na sociedade cabo-verdiana.

Neste texto, não pretendo analisar o fenómeno turístico no arquipélago, mas sim debruçar-me sobre uma ilha em particular, São Vicente, e sobre um aspecto em concreto, o carnaval. A combinação analítica entre turismo e carnaval não é incomum entre os cientistas sociais que se dedicam a uma destas temáticas, ${ }^{3}$ mas, uma vez mais, o caso cabo-verdiano tem ficado de fora das suas análises. E também

CRIA - Centro em Rede de Investigação em Antropologia; E-mail: carmodaun@gmail.com 
aqui surpreende, visto que esta festa tem ganho cada vez maior destaque na promoção turística de Cabo Verde.

O turismo constitui a principal actividade económica de Cabo Verde, representando cerca de $20 \%$ do PIB, e é assumido pelo governo como um sector estratégico e prioritário. Contudo, o desenvolvimento turístico no país faz-se a diferentes velocidades e de diferentes maneiras, consoante as ilhas e os tipos de turismo.

De um turismo quase exclusivamente de sol e mar, Cabo Verde tem tentado projectar-se de outras formas no mercado turístico internacional e diversificar a oferta. Nesse sentido, o turismo rural e o turismo histórico-cultural foram apostas recentes, cuja implementação tem sido lenta, mas cujo potencial, quer a nível nacional, quer regional, se vislumbra enorme.

Regra geral, o turismo reveste-se de uma ambivalência muito significativa. Não me refiro simplesmente às duas faces da mesma moeda, aos impactos positivos e negativos que sempre acarreta, refiro-me especialmente à multiplicidade de usos e apropriações, expectativas e motivações que ele gera ou alimenta. O mesmo se tem verificado com o carnaval de São Vicente, como espero demonstrar.

Em que medida é que certos tipos de turismo, nomeadamente o "cultural", se articulam com processos subliminares de construção e reivindicação identitária? Como é que determinadas formas de cultura expressiva (a música, a dança ou as festas populares) são instrumentalizadas para servirem os consumos turísticos e veicularem uma ideia de singularidade cultural? Que valores atribuem os actores locais ao carnaval? Quais os tipos de investimento que têm sido feitos nesta festa? Como tem sido a evolução dos discursos e práticas relativos à promoção turística do carnaval? Estes são alguns dos eixos de análise subjacentes a este artigo, onde procurarei mostrar de que forma o carnaval se revela como um recurso simultaneamente económico e cultural para os são-vicentinos. O potencial turístico da festa carnavalesca tem sido equacionado ao longo do tempo precisamente na confluência e intersecção das retóricas culturalista e economicista associadas ao carnaval. Veremos isso através do material que aqui apresento e que deriva de pesquisa etnográfica e arquivística. A abordagem qualitativa que levo a cabo procura mostrar o ponto de vista local, o lado dos hóspedes e não dos turistas, e caracterizar sumariamente o longo processo de instituição do carnaval enquanto produto turístico emblemático da ilha de São Vicente. ${ }^{4}$ Dando conta da evolução da promoção turística do carnaval, quer mediante um gradual incremento no financiamento, quer pela atribuição do valor da "tradição" ao carnaval da ilha, será possível perscrutar as facetas cultural e económica do carnaval, vertentes distintas, mas interligadas, das quais depende o êxito turístico da festa carnavalesca. Mas importa notar que o lado cultural do carnaval não tem que ver simplesmente com rótulos ou valorações, implica acima de tudo representações sociais e identitárias mais amplas. Da mesma forma, a face económica do carnaval não se revela somente no financiamento do evento, desvenda-se também na falta de retorno ou no défice da recompensa que muitos sentem.

O carnaval é um recurso de índole cultural que se tem tentado transformar num dos maiores recursos económicos de São Vicente. Esta é, aliás, uma das facetas do turismo: enquanto actividade económica, transubstancia riquezas naturais, arquitectónicas ou culturais em riquezas económicas.

O carnaval do Mindelo é uma das maiores atraç̧ões turísticas da ilha e ultimamente tem sido alvo de um interesse redobrado por parte dos agentes locais, devido sobretudo ao desejo de um maior retorno económico. Porém, os que esperam esta contrapartida têm expectativas diferenciadas e por vezes conflituantes. Município, agentes hoteleiros e empresariais, e participantes no carnaval têm ideias diferentes acerca desses dividendos, mas todos concordam no potencial turístico do carnaval.

Esta é uma festa que atrai massivamente toda a população da ilha e que chama até ela cada vez mais gente. Por altura do carnaval, São Vicente regista uma movimentação muito superior a outras épocas do ano. Os visitantes vêm das outras ilhas do arquipélago e do estrangeiro (sejam forasteiros ou emigrantes cabo-verdianos na diáspora). Uns e outros lotam voos e enchem hotéis. Contudo, este efeito supostamente positivo não tem sido suficiente e não tem chegado a quem de direito. Esta é a opinião dos que fazem o carnaval. Quanto aos que o promovem, seja governo nacional ou câmara municipal, é notório que, desde há uns anos, o investimento financeiro tem aumentado e tornou-se mesmo condição indispensável, da qual o carnaval passou a ficar dependente. Mas os investimentos no carnaval são também de outra natureza. São investimentos simbólicos que se consubstanciam em narrativas identitárias capazes de transformar certos eventos em símbolos culturais de uma ilha ou região.

Investimentos, financeiros e simbólicos, acompanhados de disputas, financeiras e simbólicas, têm caracterizado o processo de capitalização turística do carnaval de São Vicente. Vejamos então em que moldes isso tem acontecido e de que forma a cultura, ao ser constituída como recurso económico, se vai ela própria transfigurando. Este processo faz-se de correlações e alternância entre várias acepções de 
cultura: a cultura-espectáculo, a cultura-património, a cultura-tradição, e aquela em que todas estas se sustentam, a cultura-identidade, ou seja, a cultura cabo-verdiana.

\section{Carnaval: cultura e tradição}

A ilha de São Vicente é uma das nove ilhas habitadas de Cabo Verde e a sua capital, a cidade do Mindelo, é o segundo maior centro urbano do arquipélago e tem perto de 70.000 habitantes. $^{5}$

Tal como noutras ilhas, aqui pratica-se um turismo balnear, ainda que a ilha esteja mais vocacionada para outro tipo de actividades. Nos últimos anos, o turismo de cruzeiros tem aumentado e o chamado "turismo comunitário", nos bairros urbanos ou no campo, tem tentado implementar-se. Os turistas que chegam a São Vicente, seja por iniciativa individual, seja em grupo, integrados em pacotes de viagens, encontram a possibilidade de praticar um turismo balnear, mas são atraídos sobretudo pelo "turismo cultural". Este é um rótulo muitas vezes impreciso e bastante abrangente, que abarca uma diversidade de produtos e consumos turísticos, que vão desde o património material (seja arquitectónico, como casas de habitação, igrejas e outros monumentos, sejam vestígios arqueológicos) ao imaterial (como a dança, a música, as festas populares, a gastronomia), passando por uma acepção mais ampla de "cultura", que envolve as formas de ser e estar de um determinado povo ou "cultura".

Um dos expoentes máximos do turismo histórico-cultural são as classificações de Património Mundial da Humanidade da UNESCO, de que Cabo Verde tem um exemplar: a Cidade Velha, na ilha de Santiago, que obteve este estatuto em 2009. ${ }^{6}$ Estes dispositivos credenciam certos lugares ou formas culturais e funcionam como chamariz, mas o turismo cultural cobre muitas outras localidades e ofertas no arquipélago, que ficam de fora destas catalogações patrimoniais, mas que nem por isso deixam de se apresentar em termos semelhantes, isto é, como "património", "cultura" ou "tradição".

São Vicente tem muito para oferecer no que tange o turismo histórico-cultural. Desde logo, São Vicente é considerada a "ilha da cultura" e o Mindelo a "capital cultural" do país. Estes rótulos têm várias interpretações possíveis, mas, sucintamente, convocam quer a história da ilha, o seu passado cosmopolita, a sua posição de expoente máximo das letras e das artes, quer a oferta variada que ali existe ao nível de espectáculos e outros entretenimentos. Para além da fama de ser uma ilha repleta de estabelecimentos de diversão, cafés, bares, discotecas e ainda o local onde concertos e tocatinas, programados ou espontâneos, acontecem ininterruptamente - uma imagem que é uma espécie de engrandecimento do passado e desajustada da realidade corrente - São Vicente tem ainda um calendário cheio de eventos culturais.

Se considerarmos o ciclo anual da programação, é precisamente o carnaval que abre o roteiro: Carnaval, Kavala Fresk, Mindel Summer Jazz, Carnaval de Verão, Festival da Baía das Gatas, Mindelact, Passagem de Ano, são os principais eventos que anualmente animam a ilha, fazendo do Mindelo uma eventful city (Richards e Palmer 2010). Aliás, o carnaval pode ser inserido no denominado "turismo de eventos" (que abrange domínios tão díspares como os negócios, as conferências, os desportos, os festivais), não obstante em São Vicente prevalecer a designação de "turismo cultural".

$\mathrm{Na}$ verdade, se antes o Mindelo era a capital cultural do arquipélago por ser terra de músicos e escritores, este estatuto deve-se agora ao facto de ser, alegadamente, a ilha com mais eventos culturais do país. O carnaval parece inserir-se assim num roteiro turístico de espectáculos, muito mais do que num roteiro turístico de património cultural. Todavia, o carnaval é um dos maiores trunfos culturais que o município utiliza para dinamizar turisticamente a ilha. E este cartão de visita tem muito para oferecer ao turista. Para além do espectáculo convidativo dos desfiles carnavalescos, tem ainda garantida animação durante vários dias. O carnaval dá ao turista o que São Vicente se orgulha de ser: uma terra de festa e paródia. Para além de um espectáculo, o carnaval oferece ao visitante uma experiência, a partilha de uma forma de estar. ${ }^{7}$ Em compensação, o turista ocupa os hotéis, come nos restaurantes, e compra nas lojas. Mas isto não chega. E é por isso que quem é visitado tem tentado maximizar o potencial do turismo e o potencial do carnaval.

Em São Vicente, o turismo é desejado e o carnaval é tomado como um meio de atrair turistas, logo, de desenvolver o turismo na ilha.

Existem desfiles de carnaval um pouco por todo o arquipélago, mas os que mais se destacam são os das ilhas de São Vicente e de São Nicolau. Cada um destes carnavais tem a sua especificidade e, portanto, não competem directamente um com o outro, são dois cartazes turísticos independentes e até complementares, e ambos de grande importância para cada ilha. Apesar das suas diferenças, São Vicente e São Nicolau destacam-se no panorama nacional como as duas ilhas de carnaval, as ilhas onde 
ele está há mais tempo enraizado, onde ele é tradição. ${ }^{8}$ Ainda assim, quando se contrapõem estes dois carnavais, em São Vicente não se hesita em dar primazia ao carnaval local.

Ainda que diferentemente de certas festas tradicionais, o carnaval é apresentado como uma das manifestações culturais mais importantes de Cabo Verde, porque mobiliza muita gente e pode mobilizar muito mais, sobretudo turistas. Nessa mesma linha, ele tem sido apresentado como uma tradição da ilha de São Vicente. Da mesma maneira que o San Jon é automaticamente associado à ilha de Santo Antão, a Banderona à ilha do Fogo e a Tabanca à ilha de Santiago, o carnaval remete para a ilha de São Vicente e passa a ser, não somente um atractivo, mas um símbolo cultural, como as demais festividades. Não obstante algumas (o São João e o carnaval) existirem noutras ilhas do arquipélago, tornaram-se, por razões históricas e esforços recentes, festas emblemáticas de determinadas ilhas e paralelamente são também transformadas em símbolos nacionais. Assim, uma festa tanto pode ser "tradição" de uma ilha específica, como "tradição" de todo o país. As fonteiras entre uma e outra são ténues e nem sempre é claro qual a escala referida. O certo é que a carga simbólica da tradição serve propósitos mais imediatos de promoção turística e económica, mas reveste-se simultaneamente de uma apropriação de cariz "cultural" que remete para construções identitárias.

Esta "especialização" por ilhas entronca noutras questões igualmente relevantes. As disputas acerca da origem do carnaval cabo-verdiano confundem-se também com rivalidades internas, nomeadamente a que existe entre o Mindelo e a Praia, e consequentemente com a distribuição de valor turístico entre as ilhas. Em 1987, Georgina de Mello colocou a questão da mesma forma em que hoje dela se fala:

O que não chego a entender muito bem é porque se continua a insistir tanto em criar, à pressão, uma tradição do Carnaval em S. Tiago! Um Carnaval encomendado, ad-hoc, nunca será a mesma coisa. Por outro lado, não passa pela cabeça de ninguém promover o surgimento da tabanca em S. Vicente! Seria absurdo! Porque então não apoiar, promover, em cada região do nosso país as manifestações culturais que tenham raízes na cultura popular da região? Haveria assim uma especialização cultural das várias regiões, que para além do mais, teria o maior interesse para o turismo. ${ }^{9}$

\section{Ideias antigas e evolução do financiamento}

Na década de 1960, quando Cabo Verde era ainda uma colónia portuguesa, o carnaval de São Vicente já era visto como «uma festa que bem explorada poderia servir de elemento de fomento turístico». ${ }^{10}$ No dealbar dos anos 1970, encontramos a mesma ideia, numa altura em que se encara o carnaval "como indispensável no panorama turístico da ilha e da província». ${ }^{11}$ No ano seguinte, reforça-se repetidamente o intento. Chama-se a atenção de que «o corso do Mindelo, pela amplitude que está a tomar deve ser amparado e aproveitado para integrar o Carnaval de São Vicente no programa turístico da terra», ${ }^{12}$ fala-se da «integração do Carnaval do Mindelo no quadro do turismo provincial»» ${ }^{13}$ e, apelando à distanciação do carnaval brasileiro, afirma-se: «Que o Carnaval, que o nosso Carnaval, seja protegido, porque tem qualquer coisa de válido, para o futuro turístico da terra caboverdiana». ${ }^{14}$

O que estava em causa nestas conjecturas era, antes de mais, uma aspiração pelo desenvolvimento económico da terra, numa altura em que o turismo parecia ser o único meio de sobrevivência de um país pobre. Esse continua a ser, nos dias de hoje, o propósito principal do turismo em Cabo Verde.

Esse impulso que se desejava, implicava um investimento, financeiro e simbólico, na festa. Um investimento que se tem feito nos últimos anos de forma mais assumida, mas que é reclamado há muito.

É de realçar que a capitalização turística do carnaval se fez, e ainda se faz, numa articulação com a afirmação de uma identidade própria que, dependendo do contexto em questão, ora tende para uma identidade nacional, cabo-verdiana, ora recai numa identidade regional, de São Vicente. O carnaval do Mindelo é tomado como o maior e melhor, leia-se "mais verdadeiro" e "mais genuíno", carnaval cabo-verdiano.

Em 1973, a Comissão Municipal de Turismo de São Vicente, confrontada com a fraca mobilização dos grupos para o carnaval por falta de meios, decidiu «a título experimental, substituir os prémios que todos os anos são atribuídos aos primeiros classificados, por subsídios que possam ser utilizados pelos grupos na sua preparação para o desfile». E como complemento, solicitou-se às casas comerciais a atribuição de prémios pecuniários. ${ }^{15}$ Uns meses depois, a Comissão endereça outra carta, desta feita ao Director do Centro de Informação e Turismo, na capital, onde expressa o seguinte: 
Porque tais manifestações constituem uma atracção turística merecedora do amparo das entidades ligadas ao Turismo, considero importante dar a conhecer a V. Excia. que, de ano para ano, vem diminuindo o número de grupos que se incorporam no corso carnavalesco desta cidade e ainda que os poucos que o fazem vêm acusando acentuada pobreza na ornamentação dos carros alegóricos e no trajar dos seus componentes. ${ }^{16}$

Esta correspondência entre os poderes local e nacional atesta, não somente que o aproveitamento turístico do carnaval não é um desígnio recente, como também a importância que passou a assumir o investimento financeiro em articulação com o turismo. Num primeiro momento, a injecção financeira no carnaval serviu para assegurar que os desfiles se apresentassem convenientemente e assim pudessem tornar-se atractivos, evitando, ao mesmo tempo, a diminuição e decadência dos grupos carnavalescos. Mas logo passou a condição indispensável e da qual o carnaval ficou dependente, algo que se reflecte nos montantes que estão envolvidos na organização desta festa, sobretudo a partir da década de 1990 (quando o cenário político nacional se alterou profundamente e a abertura do mercado e a liberalização económica passaram a ser fomentadas como estratégia de desenvolvimento). Tal como hoje, os patrocínios ao carnaval provinham quer do governo, quer de empresas locais, bem como de alguns particulares. Em 1993 - somando o investimento estatal e municipal, bem como os donativos de várias instituições e empresas - houve um orçamento de apoio ao carnaval que ultrapassou os 2000 contos. ${ }^{17}$ Em 2011 , o orçamento global para o carnaval subiu de 7000 contos, no ano anterior, para 10.000 contos (cerca de $100.000 €) .{ }^{18}$ Estamos a falar de quantias bastante avultadas para o contexto cabo-verdiano. E estamos perante um aumento exponencial, e em progressão, do investimento no carnaval.

Actualmente - desde 2011 e falando apenas do financiamento directo - cada grupo oficial recebe da Câmara Municipal um total de 1000 contos (cerca de $10.000 €$ ), repartido em duas tranches. Como os grupos fazem questão de sublinhar, a ajuda financeira do município é bem-vinda, mas residual face às despesas que enfrentam, ${ }^{19}$ ficando muito aquém das expectativas que todos têm no que concerne aos apoios estatais. A este valor acrescentam-se ainda os patrocínios que cada grupo conseguir captar, e ainda os prémios atribuídos no final da competição aos grupos que participam no desfile oficial. ${ }^{20}$

Mas o carnaval não é somente um item numa grelha orçamental, ou um espectáculo fugaz nas ruas da cidade. Quer para a edilidade, quer para os promotores turísticos, quer para a população da ilha em geral, e para todos os envolvidos no carnaval em particular, o carnaval de São Vicente é um trunfo turístico a ser explorado. Para que este projecto se concretize, é necessário investir, não apenas financeira, mas simbolicamente no carnaval. Essa atribuição de significado faz-se das mais variadas formas. O evento que a cidade se orgulha de apresentar não é simplesmente um espectáculo, é, já vimos, património, tradição, é cultura mindelense. As músicas dos grupos carnavalescos também cantam isso:

Nôs bedje dze gente jal te fze parte d'nos cultura

Jal vra nôs tradição

Ca tchal morre nô continual ${ }^{21}$
Os nossos velhos disseram-nos que já faz parte da nossa cultura Já virou nossa tradição

Não a deixemos morrer, continuemo-la

Estas ideias não são novas. A imprensa oferece-nos prova disso mesmo. Em 1987, um articulista escreveu o seguinte:

Mas em S. Vicente explodiu, como sempre, porque é aqui o berço, a casa da qual o Rei Momo conhece todos os cantos e se sente no seu meio natural. Não sou, de modo nenhum, bairrista; (...) Por isso, sustento que o Carnaval é de e em S. Vicente (...) Com isto não quero dizer que todas as manifestações ligadas a este evento noutros pontos do país sejam travadas ou descuradas (...) o que se me afigura correcto é que os festejos sanvicentinos, por mais enraizados e representativos, devem merecer mais atenção e cuidados do que quaisquer outros; Maioritariamente os nossos fracos recursos destinados ao Carnaval cabo-verdiano (...) deverão ser canalizados para S. Vicente (...) não posso deixar de apontar que, com o desenvolvimento sério, sem recalcamentos, do Carnaval em S. Vicente, criar-se-ia, com o tempo, um pólo turístico interno e externo (...) Há muito a fazer! Há que fazê-lo, a bem da nossa Cultura, da nossa Tradição!22

Ora, é precisamente esta retórica culturalista que alavanca a retórica economicista do turismo. $\mathrm{Na}$ verdade, alimentam-se mutuamente. Insistir na sua feição patrimonial e tradicional, confere ao carnaval um valor turístico, logo económico, muito maior. E para justificar contrapartidas financeiras mais ambiciosas, o carnaval tem de ser mais do que um mero espectáculo ou evento. É voz corrente que o carnaval é cultura, é tradição, logo, é património. Ora, se o património tem de ser preservado e não se pode deixar morrer a tradição, então será impensável não promover o carnaval. Este argumento de 
lógica fácil tem sido difícil de colocar em prática. Dizem-no os responsáveis dos grupos e demonstra-o o curto historial financeiro do carnaval. Mas para que este objectivo se cumpra e para que todos beneficiem equilibradamente dele, várias medidas devem ser tomadas e todos são chamados a intervir. Além disso, é sempre reiterada a ideia de que não é apenas São Vicente que ganha com o carnaval do Mindelo, é Cabo Verde.

Uma das discussões sobre o carnaval que mais celeuma causa é a que diz respeito à distribuição das receitas e outras mais-valias do carnaval. Diz-se que os principais beneficiários são os que menos investem..$^{23}$ Esta é uma disputa entre sector privado e sector público, mas é também uma luta entre favorecidos e desfavorecidos e entre os de dentro e os de fora do campo carnavalesco.

Idealmente, o turismo deveria trazer algum retorno positivo às comunidades, e mais ainda quando depende directamente de uma acção ou esforço destas. Ora, o carnaval é feito por mindelenses que são unânimes em dizer que são os agentes turísticos, como os hotéis, as agências de viagens ou as transportadoras aéreas, que tiram proveito do carnaval, sem dar nada em troca, nem sequer um patrocínio. Há mais de uma década que este assunto se discute nestes termos, como se constata de uma carta dirigida em 2002 pelo presidente de um grupo carnavalesco à Câmara Municipal, que declara: «Urge (...) pôr cobro a esta situação, criando condições que viabilizem o bom carnaval, junto dos hotéis, restaurantes, agências de viagens, empresas televisivas e casas comerciais, em prol da nossa tradição se quisermos que viva o maior evento popular». ${ }^{24}$ No fundo, reclama-se, são eles que ganham com o carnaval e não os actores directamente envolvidos, os que fazem o carnaval e, no limite, a população em geral. Poder-se-ia argumentar que todos estes serviços contribuem para o bem-estar da ilha, quer porque criam postos de trabalho, quer porque dinamizam economicamente a cidade, mas a verdade é que esse retorno é muito residual, não chega à maioria da população e o potencial que se vislumbra no aproveitamento turístico do carnaval vai muito mais além. ${ }^{25}$

Nesta equação, o turismo equivale a dinheiro. Mas o turismo implica muito mais e pode até ser ambíguo. O turismo é desejado se trouxer dinheiro a quem de direito. Adicionalmente, o turismo traz consigo, não apenas dinheiro, mas encontros entre desconhecidos. Nem sempre o turismo, enquanto encontro cultural, é bem-sucedido. Sobretudo se o dinheiro interferir nesse encontro.

Ouvem-se, aqui e ali, alguns murmúrios xenófobos. O mais corrente ${ }^{26}$ é o de que os estrangeiros fotografam e filmam e depois ganham dinheiro com isso. Ou seja, o carnaval passa de uma manifestação de fruição colectiva a um negócio em potencial que, ainda por cima, está a ser aproveitado por outros e não por quem o faz. Até mesmo as objectivas apontadas durante o desfile desagradam a muitos, que vêem nelas perigos iminentes de comercialização lucrativa.

Seria impossível e até disparatado proibir as pessoas de fotografar ou filmar um evento de rua, espaço público por excelência, e numa performance que foi concebida precisamente para ser observada. E são, na verdade, muitos mais os que gostam de ser filmados e fotografados - chegando a pedir a turistas e locais que o façam - do que aqueles que encaram este acto com desconfiança. Mas, seguindo o raciocínio de alguns, aquilo que poderia provocar orgulho instiga antes a antipatia.

É expectável que, à medida que o carnaval se desenvolve e atinge uma maior dimensão, se vão complexificando as lutas de poder à sua volta, como aquelas que se dão entre grupos carnavalescos e grupos empresariais, e entre população local e estrangeiros. Mas, obviamente, é recomendável e desejável que se considerem os interesses dos envolvidos, nos casos em que, de facto, haja um aproveitamento abusivo, como foi o caso de uma queixa que ouvi acerca de alguém que havia tirado fotografias aos elementos de um grupo carnavalesco da cidade e estava a vendê-las a preços exorbitantes, sem qualquer autorização das pessoas retratadas.

Será útil lembrar que a hostilidade e o aproveitamento económico, e mais globalmente o jogo de forças, são aspectos muito comuns no encontro turístico. Mas também se deve reconhecer que, em muitos casos, foram o turismo e os turistas que contribuíram para a revitalização de certas manifestações culturais, sendo muitas vezes o interesse do exterior que faz nascer o interesse nas próprias comunidades. ${ }^{27}$

A visita de turistas estrangeiros também gera orgulho. Como noutros destinos turísticos, em Cabo Verde a população também rejubila quando constata que se aquela gente veio de tão longe para visitar aquela terra é porque, certamente, ela tem algo de muito especial. Mesmo que não vejam de imediato, ou não experienciem, essa atractividade, foram aprendendo os clichés inteligíveis que parecem responder a essa busca por parte dos forasteiros. Muitos deles são, aliás, os mesmos que são accionados para a caracterização da nação. É muito comum ouvir comentários que expressam a ideia do excepcionalismo (seja referente à morabeza, o povo mais hospitaleiro, ao divertimento, o povo mais festeiro, à música, o povo em que todos sabem tocar um instrumento, e muitos tropos mais). Todos estes mitos sociais estão na 
boca do povo e contribuem profunda e determinantemente para a construção da representação da nação cabo-verdiana enquanto comunidade imaginada, conforme a expressão cunhada por Anderson (1983).

\section{Esforços recentes de promoção da festa}

Ao nível governamental, várias acções têm sido levadas a cabo com vista ao desenvolvimento do carnaval. Em 2011, realizou-se em São Nicolau a primeira edição do Fórum Cultural Nacional "Carnavaleando", que reuniu artistas e dirigentes de grupos, promotores culturais, gestores públicos e outros membros da sociedade civil envolvidos na festa. Esta iniciativa inseriu-se numa tentativa de profissionalização e maior divulgação do carnaval, cuja prossecução foi entretanto interrompida. ${ }^{28}$ Em 2012, o Ministério da Cultura incrementou ainda um Plano de Sustentabilidade a ser realizado em três fases. Numa primeira fase, previa a oferta de equipamentos e materiais aos grupos oficiais; no ano seguinte, a distribuição de kits de batucada; e no terceiro ano, seriam ministrados cursos e instaladas Casas de Carnaval.

Em 2013, o ministro da Cultura anunciou que, em breve, São Vicente teria um espaço para edificar a sua Casa da Memória do Carnaval. O plano, ainda não efectivado, de se construir um Museu do Carnaval não é de agora. ${ }^{29}$ Tem mais de trinta anos. ${ }^{30}$ A ideia do museu responde aos anseios de vários actores envolvidos no carnaval, cada um com motivações distintas. Para a autarquia, seria proveitoso ter mais uma oferta cultural e mais uma instalação aberta ao público, cujas receitas pudessem reverter para o município ou ajudar a financiar o evento. Para os intervenientes do carnaval, dos presidentes aos artistas, essa seria uma das valias, mas interessa-lhes igualmente ter um espaço que lhes dê projecção e dignifique a sua actividade, que sirva para guardar e preservar as suas obras e restante acervo, sendo a questão da conservação das peças - que ou se destroem para recuperação dos materiais, ou se vendem para aquisição de fundos, ou se extraviam pelos mais variados motivos - uma das mais prementes, a par de outra, acalentada pelos artistas, que tem que ver com a sua profissionalização. É nesse sentido que muitos idealizam uma espécie de "museu vivo", um espaço que seja simultaneamente oficina de trabalho para eles e lugar visitável para os turistas ${ }^{31}$ naquilo que poderia ser considerado uma staged back region, nas palavras de MacCannell (1989 [1976]).

Enquanto o projecto museológico estatal não se materializa, a iniciativa privada faz-lhe a vez. Várias acções particulares de divulgação e promoção do carnaval têm surgido e nalguns casos, implementando o aproveitamento turístico e económico que o carnaval pode proporcionar, colmatando assim as falhas do sector público nesse domínio, com promessas sempre adiadas.

Todos os anos é possível visitar pequenas exposições de fotografias ou trajes de carnaval, organizadas por particulares ou por grupos carnavalescos, pelo menos desde a década de $1990{ }^{32}$

Mais recentemente, a presidente de um grupo carnavalesco lançou mãos à obra e ergueu o seu próprio espaço de "musealização" do carnaval. É um recinto amplo, com jardim, bar e esplanada, equipado, portanto, para receber visitantes, embora ainda não tenha aberto ao público. Conforme me disse a própria, ela pretende que o local seja ao mesmo tempo um Museu do Carnaval e um lugar de lazer para receber turistas e organizar eventos. A dimensão deste projecto tem passado despercebida à maioria dos mindelenses e a sua mentora tem vindo a desenvolvê-lo há vários anos, paulatinamente, e com recursos pessoais. Quando lá fui, ela estava confiante de que iria receber o tão esperado apoio do Ministério da Cultura, que visitou o lugar na pessoa do então ministro da tutela e seus assistentes, e prometeu apoios. A deslocação desta delegação a este "museu" de carnaval, permite perceber como convergem, em certa medida, os objectivos estatais e particulares, aliando a iniciativa pública à privada.

Deixemos as diligências locais e retomemos as nacionais. Em 2014, o Plano de Sustentabilidade pretendia tornar o carnaval mais competitivo e de qualidade, reforçando a ideia de que esta festa podia produzir riqueza, ao gerar empregos e dinamizar outros sectores. Nesse mesmo ano, foram disponibilizados fundos monetários a grupos de várias ilhas através da figura recém-criada do Banco da Cultura.

$\mathrm{Na}$ linha do aproveitamento económico do carnaval - ou, como é hoje designado, a "economia do carnaval", ou ainda as "economias criativas" - este tem sido muitas vezes apresentado como uma indústria. Se a ideia do carnaval como atracção turística não é nova, também não o é a concepção do carnaval como indústria, que remonta aos anos de $1990 .^{33}$

O modelo de produção e consumo que o termo indústria inspira não deve ser negligenciado quando analisamos o carnaval como produto turístico. O carnaval faz parte de uma indústria, seja ela turística ou cultural. Ora, uma indústria, mesmo cultural, implica a fabricação de produtos. A forte aposta no carnaval mindelense, enquanto produto turístico capaz de competir no mercado internacional, demanda 
outros formatos de apresentação e gestão. Não basta disponibilizar dinheiro e fazer investimentos financeiros. Na indústria turística, o carnaval é o produto, a mercadoria a promover e vender. E os produtos têm de ser competitivos.

Há uma notória diferença de escala relativamente aos competidores, mas Cabo Verde elegeu o carnaval como um dos seus atractivos turísticos principais e tudo tem feito para o promover além-fronteiras. Em 2015, a convite do Ministério do Turismo, Investimentos e Desenvolvimento Empresarial, vários jornalistas, de Angola, Bélgica, Espanha, França, Inglaterra, Portugal e Suíça, deslocaram-se ao Mindelo para ver de perto o carnaval. A esta delegação foi dado o nome de Fam Press Trip. ${ }^{34}$

Este grupo foi apenas um entre muitos outros que chegam à ilha e recebem o carnaval de presente. A partir de Outubro, começa a grande afluência de navios de cruzeiro à baía de São Vicente, que trazem à pequena ilha centenas de estrangeiros. É já prática comum organizarem-se recepções aos turistas com encenações de performances carnavalescas. ${ }^{35}$ Agências de viagens recrutam alguns membros de grupos de carnaval que, vestidos a rigor e ao som da batucada, mostram aos forasteiros o maior atractivo cultural da ilha.

O accionamento do carnaval para promoção turística (quer como mais um produto cultural cabo-verdiano - a par dos tamboreiros de São João, por exemplo, que também são convocados para a chegada dos cruzeiros - quer como auto-promoção do carnaval mindelense em si) é frequente e tem vindo a intensificar-se, extravasando já os limites da ilha de São Vicente. Em 2017, na ilha do Sal, a inauguração do Casino Royal, o primeiro do país, contou com Rainhas de Bateria de um grupo carnavalesco mindelense, que se deslocaram propositadamente à ilha das salinas para mostrar como se samba em São Vicente. E em Abril, o Presidente da República portuguesa também foi recebido no Mindelo com o sorriso e o samba das moças emplumadas.

Para além de um cartaz turístico em si, de um produto cultural, o carnaval tem vindo a transformar-se num cartão de visita da ilha de São Vicente. O carnaval é hoje um símbolo da ilha. E tanto assim é que não é apenas no início do ano que há carnaval em São Vicente. Refiro-me ao Carnaval de Verão que, desde 2014, se realiza no Mindelo no mês de Agosto. Esta iniciativa tem sido defendida e publicitada como uma ocasião especialmente dedicada aos emigrantes, que visitam a ilha nas suas férias de verão e que não têm a possibilidade de assistir ao carnaval do início do ano. Este carnaval estival, fora de época, apesar de ser uma pequena amostra, em número de foliões, carros alegóricos e fulgor carnavalesco, tem agradado aos visitantes e tem servido inclusive como um convite à participação no carnaval oficial. Muitos emigrantes ficam assim rendidos a esta festa e com vontade de virem assistir ou participar no carnaval de São Vicente, fazendo planos de voltar no inverno.

Mas o carnaval do Entrudo é, sem dúvida, o ex-libris da cidade e tem um poder de atraç̧ão sobre os emigrantes bastante significativo e uma expressão turística já considerável. Por essa altura, a ilha regista uma movimentação inigualável noutras épocas do ano. Os visitantes vêm das outras ilhas do arquipélago e do estrangeiro. Para este afluxo de gente muito contribuiu o aeroporto internacional Cesária Évora, inaugurado em Dezembro de $2009{ }^{36}$ Os que chegam pelo céu e pelo mar são cada vez mais. Mas no que toca especificamente aos emigrantes cabo-verdianos, de há muito que rumam à ilha pelo carnaval. Ao Mindelo chegam centenas de cabo-verdianos de toda a diáspora para assistir ou participar no carnaval. Esse fluxo fortaleceu-se a partir de 2010, quando se organizou, numa parceria com a TACV, a companhia aérea nacional, a viagem de vários cabo-verdianos emigrados nos Estados Unidos da América expressamente para o carnaval.

Mas não se pense que o trânsito intercontinental de pessoas ou as redes transnacionais de cabo-verdianos não se manifestavam bem antes da existência destas pontes aéreas. Disso nos dá conta a imprensa escrita de 1974:

(...) colocar um "bloco" na rua, com dezenas e dezenas de figurantes, trajados a rigor à base de sedas e cetins, custa muito dinheiro, é mesmo caro.

A Comissão Municipal de Turismo (...) concorrendo com 10 contos e obtendo um subsídio de 25 contos do Centro de Informação e Turismo (...) chegará a esta ilha, vinda dos Estados Unidos, uma excursão de caboverdianos radicados naquele país, precisamente para assistir ao nosso Carnaval. ${ }^{37}$

A influência da diáspora não se revela somente em solo cabo-verdiano. Nos países de acolhimento surgem também manifestações carnavalescas organizadas pelas comunidades emigradas. ${ }^{38}$

E assim, através do turismo e através do carnaval, a pequena cidade do Mindelo aspira a comunicar com o país e com o mundo. Apresenta-se orgulhosa como representante do carnaval no arquipélago e tenta, a pouco e pouco, conquistar o seu reconhecimento fora dele. 


\section{Notas finais}

Com a morna "Estrangêr é um ilusão", o músico e compositor Manuel d'Novas chamou à atenção as gentes do Mindelo de que o estrangeiro, a terra longe, não é o paraíso que eles pensam, mas sim uma vida de tormentos e canseiras, longe da família. Todavia, o estrangeiro, enquanto lugar de oportunidades ou do seu fracasso, constitui um dos valores centrais na mundividência dos cabo-verdianos e, para aqueles que nunca saíram das ilhas, permanece ainda como uma utopia por cumprir.

Em Cabo Verde, a emigração sempre serviu, e continua a servir, de trampolim para a ascensão social ou, mais eminentemente, como fuga da miséria ou busca de uma vida melhor, e a historicidade das sucessivas vagas migratórias cabo-verdianas deve ser sempre analisada em articulação com as reconfigurações económicas, sociais, familiares, estéticas e culturais a que a emigração deu origem. Ainda que afecte todos, os que partiram e os que ficaram, para muitos, o estrangeiro é ainda hoje uma miragem. Mas chega às ilhas de muitas formas. Duas delas são o turismo e a diáspora.

Se a emigração tem marcado desde o século XIX a vida do povo cabo-verdiano, o turismo tem sido encarado, desde finais do século seguinte, como a bóia de salvação que poderá inverter a sina de uma vida castigada. O turismo é tomado como uma mina de ouro, embora esteja ainda por explorar. É o que têm tentado os vários governos e os diversos agentes turísticos do arquipélago. $\mathrm{E}$ a eles tem-se juntado boa parte da população. Os modelos têm sido os mais variados e ultimamente têm-se multiplicado, ajustando-se às novas demandas do mercado, bem como a paradigmas de sustentabilidade social e ambiental. De um turismo balnear, Cabo Verde tem tentado afirmar-se como um destino multifacetado e de turismo cultural. O turismo histórico-cultural é um dos filões mais promissores e sonantes do actual panorama turístico cabo-verdiano. E tem tudo para continuar a sê-lo pois se, por um lado, é uma fonte inesgotável de riqueza e diversidade (multiplicada ainda pela especificidade de cada ilha), por outro, requer e fomenta um contacto (económico também) mais directo com as comunidades, ao contrário das bolhas turísticas que o turismo de praia e os resorts tendem a engendrar. Não é por isso de estranhar que as populações tenham também começado a percepcionar as vantagens que o turismo lhes pode trazer e, portanto, a reivindicar esse mesmo filão. Governo, agentes turísticos e população parecem estar de acordo que o turismo é algo em que devem apostar pois pode ser-lhes extremamente benéfico. Por trás deste aparente consenso há, obviamente, entendimentos díspares sobre o benefício do turismo, assim como interesses e motivações diferentes para os vários actores.

Como vimos, o carnaval, para além de um evento cultural, entre outros que a ilha oferece, é também considerado um património cultural, que se tem apresentado como uma "tradição" que é preciso promover e apoiar. Assim, se a outras ilhas se relacionam certos festejos populares, no caso de São Vicente, seria o carnaval o seu símbolo maior. Ora, esta atribuição de significado simbólico é enformadora de representações identitárias que vão muito para além de um mero espectáculo de rua. E é desta retórica culturalista que depende o sucesso económico do carnaval. Ele só será plenamente um produto turístico que agrada a todos, visitantes e visitados, quando conseguir, por um lado, exportar "cultura" e, por outro, importar "economia".

E assim, carnaval e turismo, tomados separadamente ou articulados, apresentam-se como instrumentos de desenvolvimento económico e como veículos de afirmação da identidade cultural de uma ilha, de uma região, de um povo.

\section{Bibliografia}

Anderson, Benedict.

2005 [1983]. Comunidades Imaginadas. Reflexões sobre a origem e a expansão do nacionalismo. Lisboa: Edições 70.

Bernardo, Edgar.

2015. Perceção dos impactos do turismo na ilha da Boa Vista, Cabo Verde. Tese de doutoramento. Lisboa: ISCTE.

Ferreira, Eduardo Sarmento.

2008. O Turismo Sustentável como factor de desenvolvimento das pequenas economias insulares: o caso de Cabo Verde. Lisboa: Edições Universitárias Lusófonas.

Gallinaro, Damiano.

2012. Oltre il Turismo. Scenari di mutamento nell'Arcipelago di Capo Verde. Narcissus. 
Green, Garth L.

2002. "Marketing the Nation. Carnival and tourism in Trinidad and Tobago". Critique of Anthropology 22(3): 283-304.

2007a. "Come to Life': authenticity, value, and the Carnival as cultural commodity in Trinidad and Tobago". Identities 14(1-2): 203-224.

2007b. "Authenticity, commerce, and nostalgia in the Trinidad Carnival". Em Green, Garth L. e Scher, Philip W. (Eds.), Trinidad Carnival. The Cultural Politics of a Transnational Festival, Bloomington; Indianapolis: Indiana University Press, 62-83.

Lesourd, Michel.

1995. "Le problème touristique". Em État et société aux îles du Cap-Vert. Paris: Éditions Karthala, 451-479.

Lorena Santos, Maria do Carmo.

2008 [2010]. "Imagens de um destino turístico: o caso de Cabo Verde", Forum Sociológico 18: 69-77.

2009. Turismo em Cabo Verde: um estudo exploratório. Tese de mestrado. Lisboa: Instituto de Ciências Sociais da Universidade de Lisboa.

2018. Classe, memória e identidade em Cabo Verde: uma etnografia do carnaval de São Vicente. Tese de doutoramento. Lisboa: Instituto de Ciências Sociais da Universidade de Lisboa.

MacCannell, Dean.

1989 [1976]. The Tourist. A New Theory of the Leisure Class. New York: Schocken Books.

Morales, Anamaria.

1991. "Blocos negros em Salvador: reelaboração cultural e símbolos de baianidade". Caderno CRH 4: 72-92.

Nurse, Keith.

1999. "Globalization and Trinidad Carnival: diaspora, hybridity and identity in global culture". Cultural Studies 13(4): 661-690.

Richards, Greg, e Palmer, Robert.

2010. Eventful Cities. Cultural management and urban revitalisation. London: Routledge.

Rovisco, Eduarda.

2017. "Da resistência africanista ao suvenir africano: artesanato, nação e fantasmagoria na ilha da Boa

Vista, Cabo Verde". Etnográfica 21(1): 5-26.

Scher, Philip W.

2007a. "The Devil and the Bed-Wetter. Carnival, Memory, National Culture, and Post-Colonial Conciousness in Trinidad". Western Folklore 66(1/2): 107-126.

2007b. "When 'natives' become tourists of themselves: returning transnationals and the Carnival in Trinidad and Tobago". Em Green, Garth L. e Scher, Philip W. (Eds.), Trinidad Carnival. The Cultural Politics of a Transnational Festival, Bloomington; Indianapolis: Indiana University Press, 84-101.

\author{
Periódicos: \\ O Arquipélago (vários números, 1963-1974) \\ Voz di Povo (vários números, 1979-1991) \\ Notícias (vários números, 1988-1994) \\ Novo Jornal (vários números, 1993-1998) \\ Jornal do Brasil (1995)
}

\title{
Notas
}

1 Este texto baseia-se no capítulo VII da minha tese de doutoramento em Antropologia intitulada «Classe, memória e identidade em Cabo Verde: uma etnografia do carnaval de São Vicente», defendida em 2018 no Instituto de Ciências Sociais da Universidade de Lisboa e [cuja pesquisa foi apoiada pela Fundação para a Ciência e a Tecnologia (SFRH/ $\mathrm{BD} / 77522 / 2011)$.

2 Algumas excepções são Lesourd (1995), Ferreira (2008), Lorena Santos (2008 e 2009), Gallinaro (2012), Bernardo (2015), Rovisco (2017).

3 Sobretudo nos casos do Brasil e da Trinidad, que têm dois dos carnavais mais conhecidos mundialmente e que constituem atracções turísticas internacionais. Tal como acontece com outras manifestações culturais, quando conjugado com o carnaval, o turismo é abordado normalmente em articulação com as temáticas da tradição, da autenticidade e da mercadorização (ver Green 2002, 2007a, 2007b e Scher 2007a) e, nesse sentido, da memória (ver Green 2007b e Scher 2007b, que abordaram diferentes nostalgias implicadas no carnaval da Trinidad e, sobre memória nacional, ver Scher 2007a).

4 Em trabalhos anteriores (Lorena Santos 2008 e 2009), identifiquei o carnaval como uma das imagens emblemáticas da ilha de São Vicente na promoção turística de Cabo Verde. 
5 Dados do censo de 2010, disponibilizados online pelo Instituto Nacional de Estatística de Cabo Verde.

6 Em Março de 2018, Cabo Verde submeteu à UNESCO a candidatura da morna, o género musical emblemático do país, a património mundial.

$7 \quad$ Para um aprofundamento desta ideia, ver a minha tese de doutoramento (Lorena Santos 2018).

8 Decorrente desta primazia, relativamente consensual no país, surgiu para o carnaval de 2017 uma alteração no financiamento da festa, que caiu como uma bomba entre os grupos carnavalescos da cidade da Praia, a capital do país, e que expôs claramente o regionalismo que divide as ilhas, bem como os diferentes estatutos dos vários carnavais. Os carnavais de São Vicente e São Nicolau tiveram direito a uma linha de financiamento própria denominada Carnaval Factory. Não obstante tudo isto, há por vezes disputas entre estes dois carnavais e alega-se que o de São Nicolau é o mais antigo e o mais tradicional. Veja-se, a este respeito, a crónica de opinião de José Almada Dias, «O Carnaval crioulo cabo-verdiano dos Equívocos, da Diversidade, da Indústria da Cultura, da Política, da Economia, dos Emigrantes, etc. (I)», Expresso das Ilhas online, 15 de Março de 2014, disponível em http://www.expressodasilhas.sapo.cv/opiniao/item/41670-o-carnaval-crioulo-cabo-verdiano-dos-equivocos-da-diversidade-da-industria-da-cultura-da-politica-da-economia-dos-emigrantes-etc-i Voz di Povo, n. ${ }^{\circ}$ 625, de 21 de Março de 1987, p. 6.

10 O Arquipélago, n. ${ }^{\circ} 235$, de 9 de Fevereiro de 1967, p. 2.

11 O Arquipélago, n. ${ }^{\circ} 388$, de 15 de Janeiro de 1970, p. 2.

12 O Arquipélago, n. ${ }^{\circ} 440$, de 14 de Janeiro de 1971, p. 2.

13 O Arquipélago, n. ${ }^{\circ} 442$, de 28 de Janeiro de 1971, p. 2.

14 O Arquipélago, n. ${ }^{\circ} 444$, de 11 de Fevereiro de 1971, p. 2.

15 Arquivo CMSV. Carta de 5 de Fevereiro de 1973.

16 Arquivo CMSV. Carta de 31 de Outubro de 1973.

17 Entre as instituições estatais estavam o Fundo de Desenvolvimento Nacional (com a maior fatia de investimento, $500.000 \$ 00$ ) e a Direç̧ão Geral do Turismo (que contribuiu com 100.000\$00). (Arquivo CMSV. Relatório das actividades realizadas pela Câmara Municipal de São Vicente durante o ano de 1993). Registo ainda que, dois anos depois, o Fundo de Desenvolvimento Nacional duplicou a sua contribuição. (Arquivo CMSV).

18 Ver entrevista ao vereador da Cultura publicada no blogue Dai Varela 6 de Março de 2011: "Carnaval de S. Vicente avaliado em mais de 10 Milhões de escudos», disponível em http://daivarela.blogspot.pt/2011/03/carnaval-de-s-vicente-avaliado-em-10.html

19 Para se ter uma ideia deste peso, para o carnaval de 2017 os grupos anunciavam orçamentos na ordem dos 5000 e dos 8000 contos (cf. «Grupos de São Vicente alertam os parceiros que precisam de muito mais para o Carnaval 2017», Jornal da Noite de 20 de Dezembro de 2016, TCV, disponível em http://www.rtc.cv/tcv/index.php?paginas=47\&id_cod=54112).

20 Embora a classificação dos grupos existisse pelo menos desde a década de 1960, até 1973 os prémios eram insignificantes - quatro, totalizando 8000 escudos - e é solicitado ao Centro de Informação e Turismo um subsídio bem maior (Arquivo CMSV. Carta de 31 de Outubro de 1973).

21 Trecho de "Kes Estória", música da autoria de Zé Bentub, grupo Cruzeiros do Norte, carnaval de 2011. Arquivo IC-CCP.

22 Voz di Povo, n. ${ }^{\circ}$ 623, de 14 de Março de 1987, pp. 3-5.

23 Nurse (1999:679) registou o mesmo para o caso do carnaval de Trinidad.

24 Arquivo CMSV. Carta de 12 de Janeiro de 2002.

25 Apesar de ser uma reclamação antiga, em 2012, a ADEI (Agência para o Desenvolvimento Empresarial e Inovação) promoveu no Mindelo um encontro sobre a chamada "economia do carnaval" com o intuito de conhecer os operadores e os negócios gerados pelo carnaval de forma a conseguir-se uma distribuição equitativa por todos. Veja-se a reportagem "ADEI quer fomentar economia do carnaval em São Vicente», Jornal da Noite de 12 de Maio de 2012, TCV, disponível em http://www.rtc.cv/index.php?paginas=13\&id_cod=17604

26 Mas nem por isso exclusivo do contexto cabo-verdiano. Há relatos de descontentamentos semelhantes, por exemplo, no Brasil (cf. Morales 1991:82).

27 Considere-se, a título de exemplo, o que se passa com o artesanato em Cabo Verde, na sua faceta potencialmente lucrativa por via do turismo. Na Praça Estrela, muitos imigrantes da costa ocidental africana vendem artesanato dessa região a turistas ingénuos ou desinformados, que o compram como sendo cabo-verdiano, ou talvez se contentem por ser "africano". Nos últimos anos, tem-se registado um crescimento assinalável do interesse e da produção de artesanato por parte da população. Esse artesanato tem sido inscrito com motivos "locais", sejam eles a simples marcação das palavras "Cabo Verde" no produto, seja a multiplicação de imagens associadas à terra (trapiche, pilão, tartarugas, etc.). Este fenómeno, ainda muito pouco explorado no contexto cabo-verdiano, mereceria a dedicação de olhares antropológicos. Veja-se Rovisco (2017) que abordou a venda de souvenirs por imigrantes senegaleses na ilha da Boavista.

28 Este projecto inseria-se num plano mais global de desenvolvimento económico e foi promovido com o apoio da Conferência das Nações Unidas sobre Comércio e Desenvolvimento (UNCTAD). A nível nacional, o Plano Estratégico Integrado para o Desenvolvimento das Economias Criativas de Cabo Verde - Plano Cabo Verde Criativo delineava as estratégias prioritárias para o desenvolvimento das economias criativas do país, sendo o carnaval uma delas. Em 2016, após a mudança do Governo, o recém-criado e doravante denominado Ministério da Cultura e das Indústrias Criativas extinguiu o Fórum e iniciou um novo plano para o desenvolvimento do carnaval.

29 Inclusive, algumas peças carnavalescas, nomeadamente trajes, foram adquiridas pela Câmara Municipal e encontram-se armazenadas há alguns anos na Academia de Música Jotamonte, mas sem visibilidade pública.

30 Cf. Voz di Povo, n. ${ }^{\circ}$ 293, de 5 de Março de 1982, p. 4.

31 Uma inspiração decalcada da Cidade do Samba no Rio de Janeiro.

32 Arquivo CMSV.

33 Cf. Novo Jornal, de 2 de Março de 1993.

34 Deduz-se que não apenas Press Trip porque, para além dos jornalistas, havia também "famosos" (daí a abreviatura Fam), como dois jovens actores portugueses. De Angola, veio o escritor José Eduardo Agualusa. Esta delegação foi recebida no aeroporto da ilha ao som de batucada e por foliões que sambavam vestidos a preceito, todos convocados para a recepção. 
35 Embora estas iniciativas se tenham generalizado recentemente, elas começaram há muito tempo, remontam ao final da década de 1980.

36 Até aí, as entradas na ilha por via aérea faziam-se com escala noutras ilhas (Sal ou Praia, os únicos aeroportos com ligações internacionais).

37 O Arquipélago, n. ${ }^{\circ}$ 597, de 17 de Janeiro de 1974, p. 2. Registo ainda a organização de excursões turísticas do Rio de Janeiro, anunciadas num jornal brasileiro da seguinte forma: «Carnaval na África (Cabo Verde) São 10 ilhas que formam este país hospitaleiro, alegre e seguro, sem contar o festivo Carnaval de Mindelo (opcional)». Jornal do Brasil, de 25 de Janeiro de 1995, p. 2.

38 Estas replicações carnavalescas nos países de acolhimento têm no caso trinidadiano um exemplo sobejamente conhecido, nomeadamente com o carnaval de Notting Hill em Londres ou o de Brooklyn em Nova Iorque. A respeito da relação entre o carnaval de e em Trinidad e a sua comunidade emigrada, ver Scher (2007b). 